\title{
Sorbent Carbon Development Task 5.2
}

Topical Report

January 1994 - June 1995

Ronald C. Timpe

November 1995

Work Performed Under Contract No.: DE-FC21-93MC30097

For

U.S. Department of Energy

Office of Fossil Energy

Morgantown Energy Technology Center

Morgantown, West Virginia

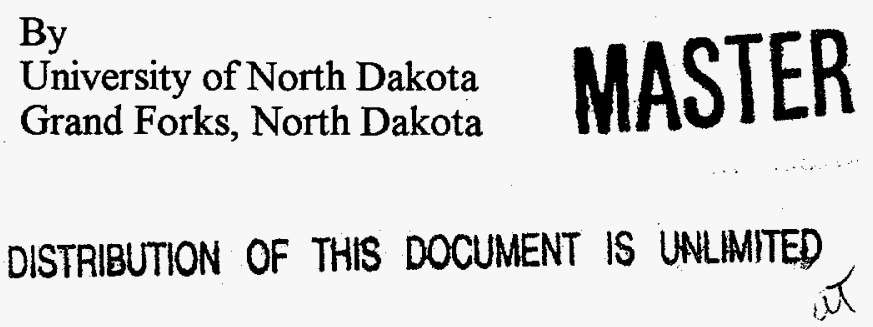




\section{DISCLAIMER}

This report was prepared as an account of work sponsored by an agency of the United States Government. Neither the United States Government nor any agency thereof, nor any of their employees, makes any warranty, express or implied, or assumes any legal liability or responsibility for the accuracy, completeness, or usefulness of any information, apparatus, product, or process disclosed, or represents that its use would not infringe privately owned rights. Reference herein to any specific commercial product, process, or service by trade name, trademark, manufacturer, or otherwise does not necessarily constitute or imply its endorsement, recommendation, or favoring by the United States Government or any agency thereof. The views and opinions of authors expressed herein do not necessarily state or reflect those of the United States Government or any agency thereof.

This report has been reproduced directly from the best available copy.

Available to DOE and DOE contractors from the Office of Scientific and Technical Information, 175 Oak Ridge Turnpike, Oak Ridge, TN 37831; prices available at (615) 576-8401.

Available to the public from the National Technical Information Service, U.S. Department of Commerce, 5285 Port Royal Road, Springfield, VA 22161; phone orders accepted at (703) 487-4650. 


\title{
Sorbent Carbon Development Task 5.2
}

\author{
Topical Report \\ January 1994 - June 1995
}

Ronald C. Timpe

Work Performed Under Contract No.: DE-FC21-93MC30097

\author{
For \\ U.S. Department of Energy \\ Office of Fossil Energy \\ Morgantown Energy Techniology Center \\ P.O. Box 880 \\ Morgantown, West Virginia 26507-0880 \\ By \\ University of North Dakota \\ Energy \& Environmental Research Center \\ P.O. Box 9018 \\ Grand Forks, North Dakota 58202-9018
}




\section{ACKNOWLEDGMENT}

This final report was prepared with the support of the U.S. Department of Energy (DOE), Morgantown Energy Technology Center, Cooperative Agreement No. DE-FC21-93MC30097.

However, any opinions, findings, conclusions, or recommendations expressed herein are those of the author(s) and do not necessarily reflect the views of the DOE. 


\section{TABLE OF CONTENTS}

LIST OF FIGURES $\ldots \ldots \ldots \ldots \ldots \ldots \ldots \ldots \ldots \ldots \ldots \ldots \ldots \ldots \ldots$

LIST OF TABLES $\ldots \ldots \ldots \ldots \ldots \ldots \ldots \ldots \ldots \ldots \ldots \ldots \ldots \ldots \ldots \ldots \ldots$

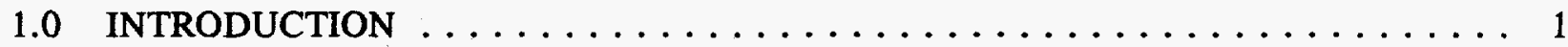

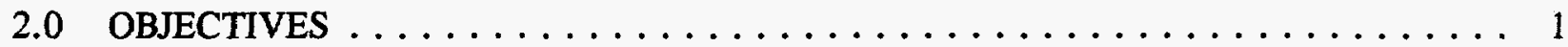

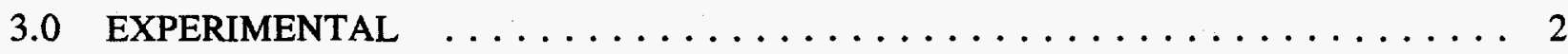

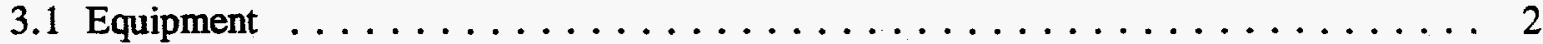

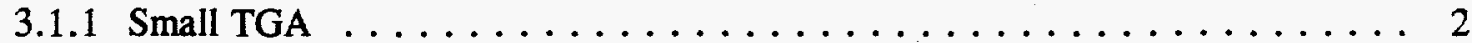

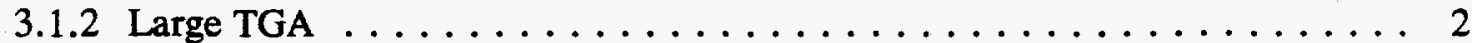

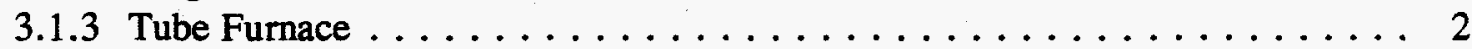

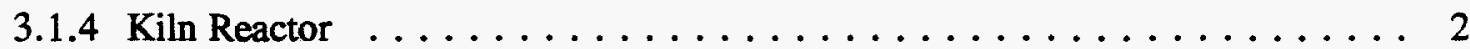

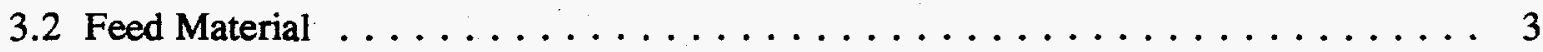

3.3 Test Plan - Sorbent Preparation and Testing $\ldots \ldots \ldots \ldots \ldots \ldots \ldots$

3.4 Physical Cleaning of Leonardite $\ldots \ldots \ldots \ldots \ldots \ldots \ldots \ldots \ldots \ldots \ldots \ldots$

3.5 Chemical Cleaning ....................... 4

3.6 Physical Measurements on Activated Chars $\ldots \ldots \ldots \ldots \ldots \ldots$

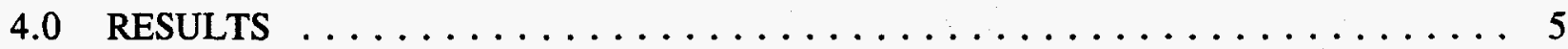

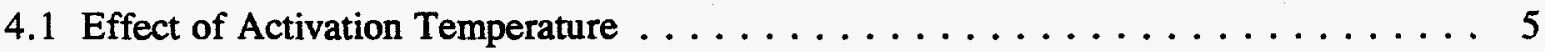

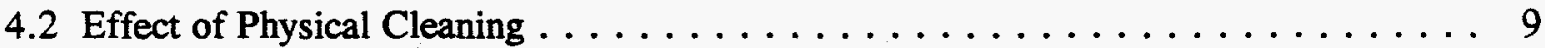

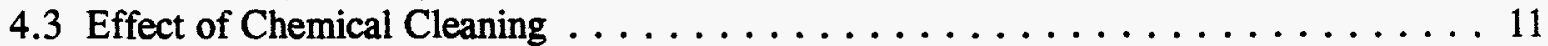

4.4 Surface Area and Porosity of Selected Samples $\ldots \ldots \ldots \ldots \ldots \ldots \ldots$

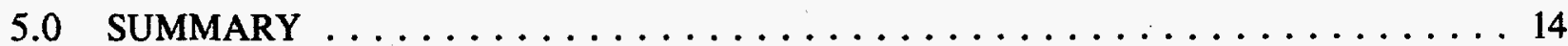

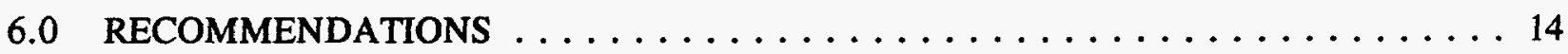

7.0 PAPERS AND PRESENTATIONS $\ldots \ldots \ldots \ldots \ldots \ldots \ldots \ldots \ldots$

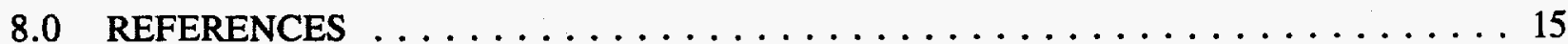




\section{LIST OF FIGURES}

1 Proximate analysis of raw leonardite, leonardite carbonized at $480^{\circ} \mathrm{C}$, and steam-activated

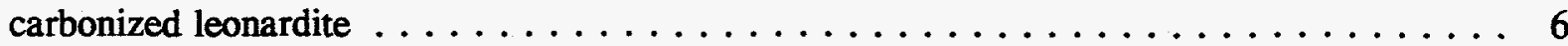

$2 \mathrm{SO}_{2}$ adsorption from flowing gas containing $5000 \mathrm{ppm} \mathrm{SO} \mathrm{S}_{2}$ in argon at ambient temperature . 7

$3 \mathrm{SO}_{2}$ adsorption from $5000 \mathrm{ppm} \mathrm{SO}_{2}$ in argon at $100^{\circ} \mathrm{C} \ldots \ldots \ldots \ldots$

4 Ratio of $\mathrm{SO}_{2}$ sorption capacity at ambient temperature to sorption capacity at $100^{\circ} \mathrm{C}$ versus steam activation temperature $\ldots \ldots \ldots \ldots \ldots \ldots \ldots \ldots \ldots \ldots \ldots$

5 Sorptive capacity for $I_{2}$ of chars steam-activated at increasing temperatures $\ldots \ldots \ldots$

\section{LIST OF TABLES}

1 Proximate Analysis of Two North Dakota Leonardites $\ldots \ldots \ldots \ldots \ldots$

2 XRFA Analysis of Georesources Leonardite and Gascoyne Leonardite Ash . . . . . . . . 4

3 Activation Conditions for Leonardite Carbonized at $480^{\circ} \mathrm{C}-$ Test Plan $1 \ldots \ldots$

4 Proximate Analysis of As-Received Raw Leonardite, Leonardite Char Carbonized under $\mathrm{N}_{2}$ at $480^{\circ} \mathrm{C}$ and Activated at $750^{\circ} \mathrm{C}$, and Chemically Cleaned Leonardite $\ldots \ldots \ldots$

5 Proximate Analysis of Georesources Leonardite Sink-Float Fractions . . . . . . . . . . 10

6 Ash Reduction and Solids Recovery from Washability Testing of Leonardite . . . . . . . 10

$7 \mathrm{SO}_{2}$ Sorption by Leonardite Char Prepared from Raw and Chemically Cleaned Leonardite

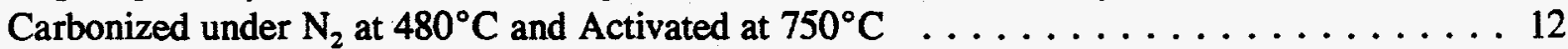

8 BET $\left(\mathrm{N}_{2}\right)$ Surface Area of Treated Leonardite and Other Experimental and Commercial

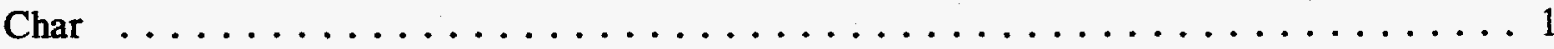

9 Pore Structural Characterization of Commercial and North Dakota LRC Carbon . . . . . . . 13 


\section{TASK 5.2 SORBENT CARBON DEVELOPMENT}

\subsection{INTRODUCTION}

Chars and other carbons, in granular or powdered form, are in high demand worldwide for environmental applications associated with energy production and by-product recovery. Carbons for gas-phase cleanup (sulfur gases, $\mathrm{NO}_{\mathrm{x}}$, and trace element removal) and liquid-phase cleanup (organics removal) sell for several hundred to several thousand dollars per ton, depending upon grade and end use. In general, these carbons have undergone an activation process, i.e., steam or $\mathrm{CO}_{2}$. Commercial sorbent carbons are derived largely from coal and biomass sources such as coconut shells and wood. Bituminous coals have been typically used for producing hard, large-pore-volume carbons for gas and vapor applications. Lignite carbons, with a hard, small-pore-volume texture, have been preferred in wastewater treatment. Information on the relative effectiveness of bituminous and lignite coal carbons is not readily available. Also, information is needed on the extent to which various preparation and metal ion impregnation procedures can alter structure, gas sorption capacity, and selectivity to develop low-cost supersorbents. Hence the need exists to develop methods to demonstrate the feasibility of utilizing lignites and allied materials (e.g., leonardite) as effective gas or vapor sorbents.

Activated carbon is used as an adsorbent in all aspects of fluids cleanup, including acid gas and toxic trace metals removal from combustion flue gases resulting from electrical generation and waste incineration, removal of heavy metal and organic contaminants of water, and removal of organic vapors from liquid fuel systems to prevent volatile organic emissions (VOCs). The cost of activated carbon produced from traditional feeds such as coconut shells, bones, and other carbonaceous material becomes prohibitive in the quantities required to satisfy all of these needs. An obvious substitute for these feeds is coal, which, because of its large reserves and availability, makes a much less expensive carbon source. Pyrolysis of coal, followed by activation with a reactant gas, has been shown to produce a satisfactory substitute for the activated carbon produced from the previously mentioned activated feedstocks. North Dakota has large reserves of lignite and leonardite (naturally weathered lignite) from which a useful activated carbon product (char) can potentially be manufactured. This project is directed toward producing activated carbon from a leonardite and lignite optimized for specific applications in gas and water cleanup.

\subsection{OBJECTIVES}

The primary objective of this study is to transform low-rank coals (LRCs) into effective sorbent carbons economically for gas- and liquid-phase contaminant removal.

Specific objectives for 1994 are detailed as follows:.

- To determine the relative ranking of powdered and granulated carbons prepared from a lignite or leonardite with those of commercial carbons derived from bituminous coals or other raw materials for the sorption of sulfur-containing gases and mercury. 
- To examine the effect of coal properties (e.g., rank, chemistry, ash content, and composition), metal ion impregnation, and carbon preparation and granulation (size enlargement) on gas-phase adsorption properties.

\subsection{EXPERIMENTAL}

\subsection{Equipment}

The activated carbon preparations were carried out on milligram, gram, and kilogram quantities of feed material. They were typically performed in two steps, i.e., a carbonization step followed by an activation step. A brief description of the reactors used for preparing the carbons follows.

\subsubsection{Small TGA}

Preliminary parametric studies of preparation of activated char from LRCs were carried on a TA Instruments 951 thermogravimetric analyzer (TGA) interfaced with a model 2100 controller/data station. Approximately $50 \mathrm{mg}$ of the coal was carbonized by heating to a target temperature (usually $480^{\circ} \mathrm{C}$ ) under inert atmosphere and holding at that temperature for a predetermined period of time. The sample was then activated by heating at a second target temperature under inert gas or inert gas followed by steam for a second predetermined period of time. The char was then characterized by $\mathrm{SO}_{2}$ adsorption and, in selected cases, by proximate analysis.

\subsubsection{Large TGA}

A large-capacity TGA was built at the Energy \& Environmental Research Center (EERC) to carry out TGA experiments with larger quantities of material. The unit was built using a Cahn 1000 electrobalance and temperature controller and is interfaced to a microcomputer. In this study, the sample (limited by sample bulk) was loaded into a high-temperature stainless steel wire mesh basket, heated at $30^{\circ} \mathrm{C} / \mathrm{min}$ in a flowing $\mathrm{N}_{2}$ gas stream to target temperatures of $700^{\circ}, 750^{\circ}, 800^{\circ}$, or $850^{\circ} \mathrm{C}$, and reacted with steam. Higher temperatures are not available on this instrument, so a tube furnace was used for activation at the higher temperatures.

\subsubsection{Tube Furnace (TF)}

A Lindberg Type 59344 TF was used to activate the char at temperatures of $800^{\circ}, 850^{\circ}, 900^{\circ}$, $950^{\circ}$, and $1000^{\circ} \mathrm{C}$ after carbonization. The heating chamber is 19 in. long and accommodated the 1-in.-OD Vycor tube, which was used as the reactor vessel when the char was activated.

\subsubsection{Kiln Reactor}

A new reactor used for carbonizing or carbonizing and activating feedstock is first described. The kiln reactor was assembled from a Cress Model X31TC kiln containing a stainless steel cylindrical vessel wrapped on the outside with stainless tubing. The kiln is rated for $2500^{\circ} \mathrm{F}$ $\left(1370^{\circ} \mathrm{C}\right)$. The vessel, which has a capacity of 2700 in. $^{3}\left(44,480 \mathrm{~cm}^{3}\right)$, is designed to be operated in the fixed-bed mode. It has a distributer plate on the bottom through which gas, preheated by the kiln as it passes through the external coils on the vessel, enters to permeate the coal bed. The tars, oils, 
moisture, and effluent gases exit through the top of the vessel and pass through a series of two aircooled condensers before being vented to the outside of the building.

\subsection{Feed Material}

The work carried out in this project primarily involved $-12 \times+30$-mesh North Dakota leonardite, a highly oxygenated LRC. The ash content of the Georesources leonardite, the principal char source, was significantly higher than expected, as shown in Table 1. Moisture-free ash was $28 \mathrm{wt} \%$ as compared to $15 \mathrm{wt} \%$ in the leonardite from the same source as obtained in 1991, the latter being one of the two best $\mathrm{SO}_{2}$ sorbents in a suite of 18 coals tested in a preliminary screening of LRCs for char sorbent preparation. Because of the disparity in gross composition between this lot and the 1991 lot, proximate analysis was carried out on samples of raw Georesources leonardite and on raw Gascoyne leonardite, also from North Dakota, as well as x-ray fractionation (XRF) analysis on the ash of the leonardites. The results of these analyses are shown in Tables 1 and 2, respectively. Reduction of ash content was partially accomplished by grinding the coal and preparing the activated carbon from the $-12 \times 30$-mesh fraction.

\subsection{Test Plan - Sorbent Preparation and Testing}

Preliminary carbon preparation testing was carried out on the small TGA. The sample was carbonized at one temperature $\left(250^{\circ}, 350^{\circ}, 480^{\circ}\right.$ or $\left.550^{\circ} \mathrm{C}\right)$ under inert gas for selected time, then activated at a higher temperature $\left(700^{\circ}-1000^{\circ} \mathrm{C}\right)$ under inert or reactive gas for a selected time, then cooled. The resulting carbon was characterized by $\mathrm{SO}_{2}$ adsorption at ambient temperature or $100^{\circ} \mathrm{C}$. Conditions for carbon preparation at a larger scale were selected based on the results of the tests carried out on the small TGA and are shown in Table 3.

The activated chars prepared on a larger scale were characterized using the following:

- TGA proximate analysis

- $\mathrm{SO}_{2}$ sorption at ambient temperature

- Iodine number

- BET surface area (selected samples)

- Porosity (selected samples)

\section{TABLE 1}

Proximate Analysis of Two North Dakota Leonardites

\begin{tabular}{lccccc}
\hline & \multicolumn{2}{c}{ Georesources Leonardite } & & \multicolumn{2}{c}{ Gascoyne Leonardite } \\
\cline { 2 - 3 } \cline { 5 - 6 } \cline { 5 - 6 } & As-Received & Moisture-Free & & As-Received & Moisture-Free \\
\hline \multirow{2}{*}{ Moisture, wt\% } & 32.6 & - & & 42.1 & - \\
Volatiles, wt\% & 29.8 & 44.1 & & 28.6 & 490.4 \\
Fixed Carbon, wt\% & 18.6 & 27.6 & & 21.6 & 37.2 \\
Ash, wt\% & 19.1 & 28.3 & & 7.0 & 12.0 \\
\hline
\end{tabular}




\section{TABLE 2}

XRF Analysis of Georesources Leonardite and Gascoyne Leonardite Ash

\begin{tabular}{|c|c|c|c|c|c|c|}
\hline & \multicolumn{3}{|c|}{ Georesources Leonardite } & \multicolumn{3}{|c|}{ Gascoyne Leonardite } \\
\hline & $\begin{array}{c}\text { Ash as } \\
\text { Element, } \\
\text { wt \% }\end{array}$ & $\begin{array}{c}\text { Ash as } \\
\text { Oxide, } \\
\text { wt \% }\end{array}$ & $\begin{array}{c}\text { Coal as } \\
\text { Element, } \\
\text { wt } \%\end{array}$ & $\begin{array}{c}\text { Ash as } \\
\text { Element, } \\
\text { wt \% }\end{array}$ & $\begin{array}{c}\text { Ash as } \\
\text { Oxide, } \\
\text { wt \% }\end{array}$ & $\begin{array}{c}\text { Coal as } \\
\text { Element, } \\
\text { wt } \%\end{array}$ \\
\hline Silica, $\mathrm{SiO}_{2}$ & 12.8 & 27.4 & 3.6 & 9.7 & 20.8 & 1.2 \\
\hline Aluminum Oxide & 8.1 & 15.4 & 2.3 & 6.5 & 12.2 & 0.8 \\
\hline Ferric Oxide & 4.8 & 6.9 & 1.4 & 9.6 & 13.7 & 1.2 \\
\hline Titanium Oxide & 0.3 & 0.5 & 0.1 & 0.3 & 0.5 & - \\
\hline $\begin{array}{l}\text { Phosphorus } \\
\text { Pentoxide }\end{array}$ & 0.1 & 0.3 & - & 0.1 & 0.2 & - \\
\hline Calcium Oxide & 11.8 & 16.5 & 3.3 & 14.1 & 19.8 & 1.7 \\
\hline Magnesium Oxide & 4.5 & 7.4 & 1.3 & 6.4 & 10.7 & 0.8 \\
\hline Sodium Oxide & 0.6 & 0.8 & 0.2 & 0.7 & 0.9 & 0.1 \\
\hline Potassium Oxide & 0.6 & 0.7 & 0.2 & 0.3 & 0.4 & - \\
\hline Sulfur Trioxide & 8.8 & 22.0 & 2.5 & 6.6 & 16.4 & 0.8 \\
\hline Total & 52.4 & 97.8 & 14.9 & 54.3 & 95.5 & 6.5 \\
\hline
\end{tabular}

\subsection{Physical Cleaning of Leonardite}

Washability testing was performed on raw leonardite using Certigrav at specific gravity 1.4 and 1.6. The float fractions were carbonized at $480^{\circ} \mathrm{C}$ under $\mathrm{N}_{2}$ and activated at $750^{\circ} \mathrm{C}$ under steam on the small TGA. The carbon was characterized with $\mathrm{SO}_{2}$ adsorption.

Two hundred ninety pounds of +3-mesh leonardite was cleaned by density separation using a dense medium (magnetite). The float fraction recovered weighed 169 pounds. Twelve kilograms of the float fraction from the dense-media separation was carbonized in the kiln reactor at temperatures of $480^{\circ} \mathrm{C}$ and $350^{\circ} \mathrm{C}$ under flowing $\mathrm{N}_{2}$. Each carbonized fraction was activated at $750^{\circ} \mathrm{C}$ under steam.

\subsection{Chemical Cleaning}

The mineral content of the leonardite is quite high as indicated by the proximate analysis shown in Table 1. A sample of leonardite was washed with hot $4.8 \mathrm{M} \mathrm{HCl}$, in a manner similar to that prescribed in the ASTM D2492 for removal of pyrite from coal. A second sample was chemically cleaned with $\mathrm{HCl}$ followed by a cleaning with $\mathrm{HF}$. The chemically cleaned samples were washed thoroughly to remove residual acid and water soluble salts and dried at $105^{\circ} \mathrm{C}$ under flowing $\mathrm{N}_{2}$ gas. Proximate analyses were carried on the chemically cleaned leonardite and the results are shown in Table 4. The chemically cleaned leonardite samples were then carbonized and activated for 60 minutes under steam in a vertical tube reactor. 


\section{TABLE 3}

Activation Conditions for Leonardite Carbonized at $480^{\circ} \mathrm{C}$ - Test Plan 1

\begin{tabular}{cccccc}
\hline Test No. & $\begin{array}{c}\text { Sample Size, } \\
\mathbf{g}\end{array}$ & Reactor & Atmosphere & $\begin{array}{c}\text { Temperature, } \\
{ }^{\circ} \mathrm{C}\end{array}$ & $\begin{array}{c}\text { Time, } \\
\text { min }\end{array}$ \\
\hline 1 & 10 & TGA & $\mathbf{N}_{2}$ & 700 & 10 \\
2 & 10 & TGA & $\mathbf{N}_{2}$ & 750 & 10 \\
3 & 10 & TGA & $\mathbf{N}_{2}$ & 800 & 10 \\
4 & 10 & TGA & $\mathbf{N}_{2}$ & 850 & 10 \\
5 & 50 & TF & $\mathbf{N}_{2}$ & 800 & 10 \\
6 & 50 & TF & $\mathbf{N}_{2}$ & 850 & 10 \\
7 & 50 & TF & $\mathbf{N}_{2}$ & 900 & 10 \\
8 & 50 & TF & $\mathbf{N}_{2}$ & 950 & 10 \\
9 & 50 & TF & $\mathbf{N}_{2}$ & 1000 & 10 \\
10 & 12000 & Kiln & $\mathbf{N}_{2}$ & 750 & 60 \\
11 & 12000 & Kiln & $\mathbf{N}_{2} / \mathbf{H}_{2} \mathrm{O}$ & 750 & 60 \\
\hline
\end{tabular}

\subsection{Physical Measurements on Activated Chars}

Surface areas were determined according to the Brunauer-Emmett-Teller (BET) technique using $\mathrm{N}_{2}$ as the adsorbate. Bulk volume was determined by $\mathrm{Hg}$ displacement using a Ruska mercury porometer. Pore volume was determined using the same instrument and pressurizing to an instrument standard of 750 psig.

\subsection{RESULTS}

\subsection{Effect of Activation Temperature}

Properties of the char produced from leonardite according to the test plan are illustrated in Figures 1-5. Figure 1 shows the proximate analysis of raw leonardite, leonardite carbonized at $480^{\circ} \mathrm{C}$, and carbonized leonardite, i.e., leonardite char, activated with steam at temperatures from $700^{\circ}$ to $1000^{\circ} \mathrm{C}$ in $50^{\circ} \mathrm{C}$ intervals. The only trend seen in the figure is a decrease in volatiles. These volatiles at the higher temperature are probably not indigenous to the coal, but are surfaceadsorbed gases occurring on exposure of the activated char to air. This being the case, the lower level of volatiles implies a less active char carbon. 


\section{TABLE 4}

Proximate Analysis of As-Received Raw Leonardite, Leonardite Char Carbonized under $\mathrm{N}_{2}$ at $480^{\circ} \mathrm{C}$ and Activated at $750^{\circ} \mathrm{C}$, and Chemically Cleaned Leonardite.

\begin{tabular}{|c|c|c|c|c|c|c|}
\hline Treatment & Atmosphere & Time, $\min$ & $\begin{array}{c}\text { Moisture, } \\
\text { wt\% as- } \\
\text { rec'd. }\end{array}$ & $\begin{array}{c}\text { Volatile } \\
\text { Matter, } \\
\text { wt\% } \\
\text { moisture- } \\
\text { free } \\
\end{array}$ & $\begin{array}{c}\text { Fixed } \\
\text { Carbon, } \\
\text { wt } \% \\
\text { moisture- } \\
\text { free } \\
\end{array}$ & $\begin{array}{c}\text { Ash, } \\
\text { wt\% } \\
\text { moisture- } \\
\text { free } \\
\end{array}$ \\
\hline Raw & - & - & 32.6 & 44.1 & 27.6 & 28.3 \\
\hline Raw & Steam & 20 & 1.0 & 8.5 & 53.7 & 37.9 \\
\hline $\mathrm{HCl}$ Leach & Steam & 60 & 0.9 & 48.3 & 44.9 & 6.8 \\
\hline $\begin{array}{l}\mathrm{HCl}, \mathrm{HF} \\
\text { Leach }\end{array}$ & Steam & 60 & 7.0 & 51.5 & 48.1 & 0.4 \\
\hline
\end{tabular}

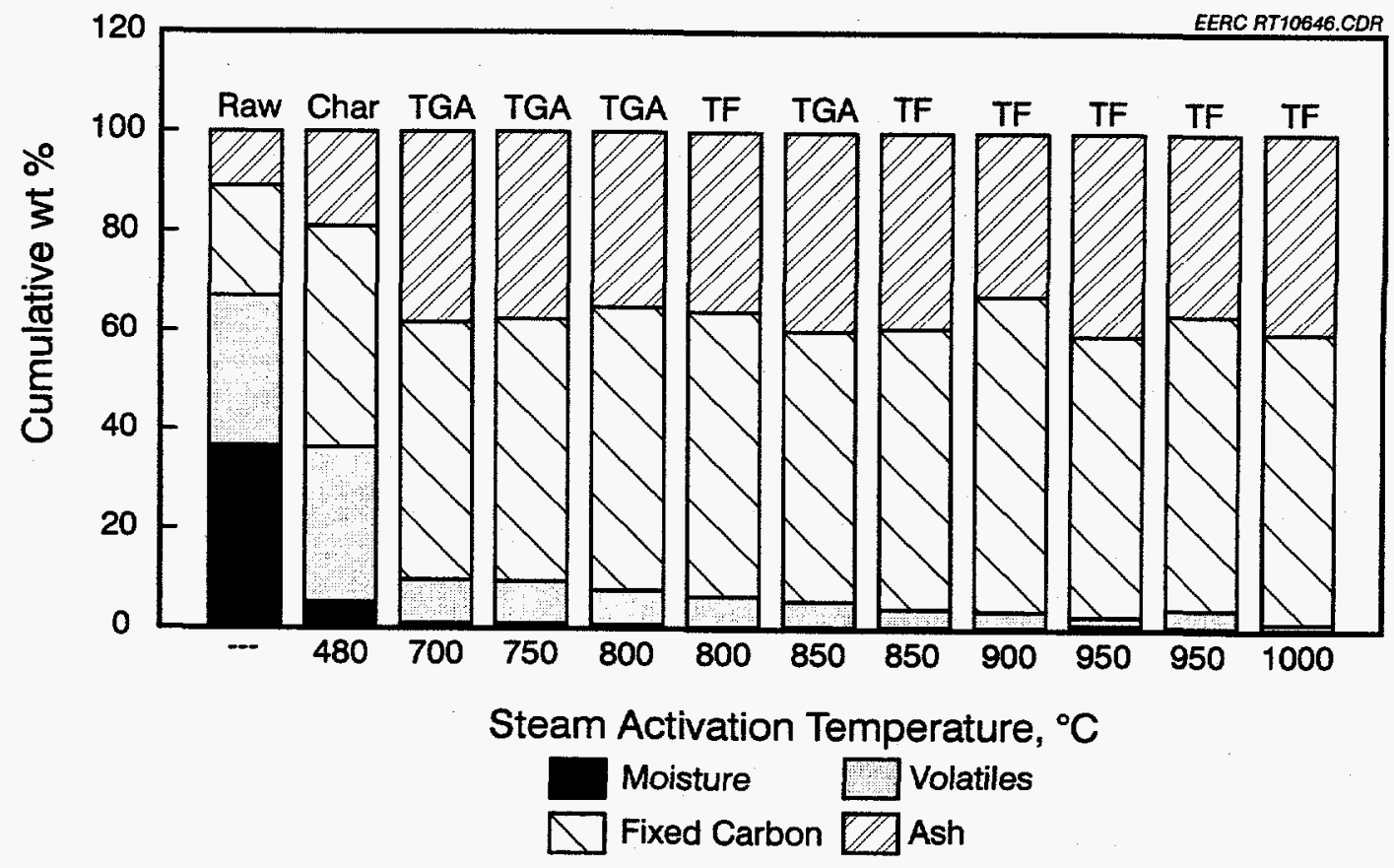

Figure 1. Proximate analysis of raw leonardite, leonardite carbonized at $480^{\circ} \mathrm{C}$, and steamactivated carbonized leonardite. 


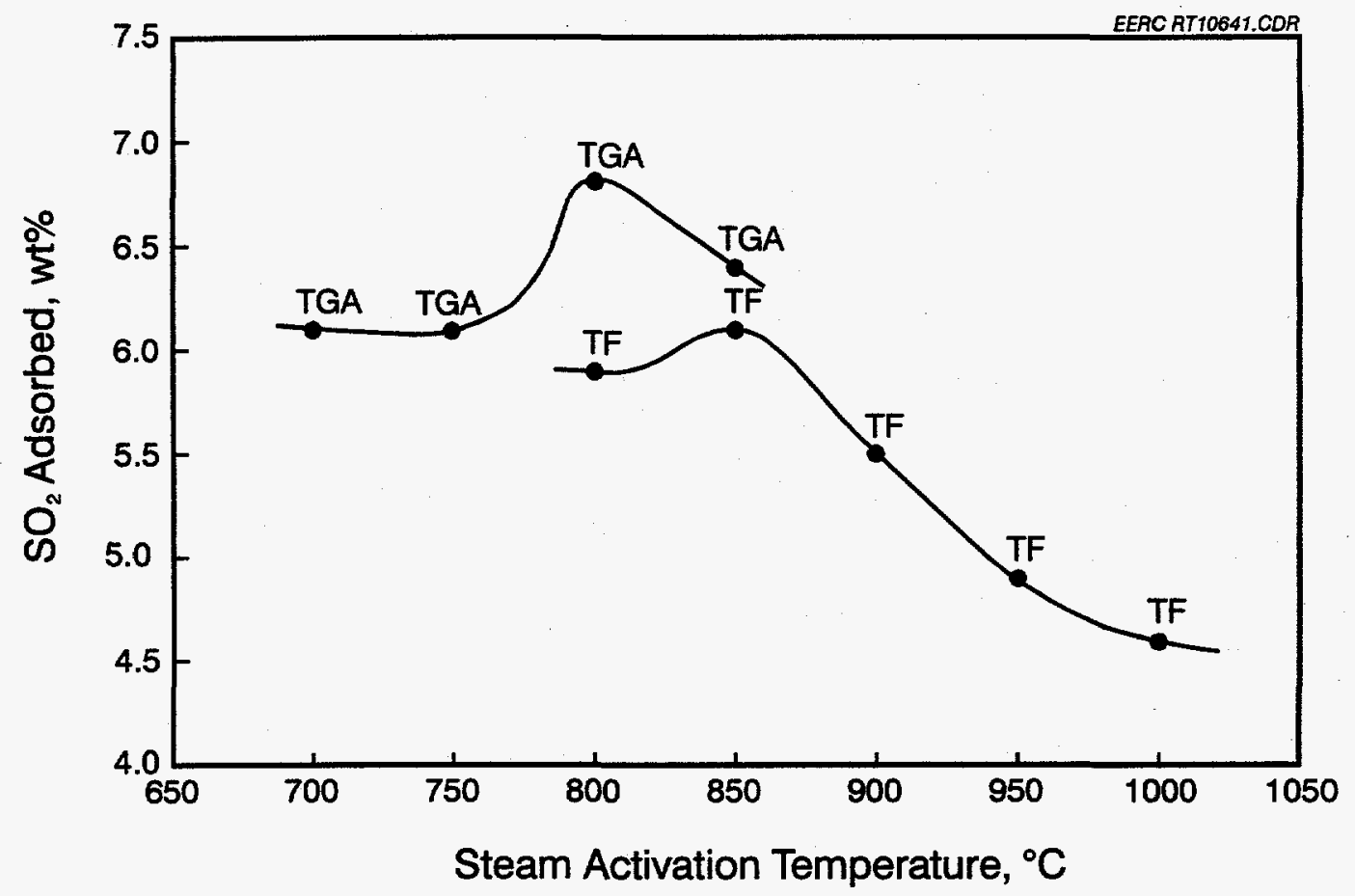

Figure 2. $\mathrm{SO}_{2}$ adsorption from flowing gas containing $5000 \mathrm{ppm} \mathrm{SO}_{2}$ in argon at ambient temperature. Chars activated at $700^{\circ}, 750^{\circ}$, and $850^{\circ} \mathrm{C}$ have similar sorption capacities when tested at ambient temperature.

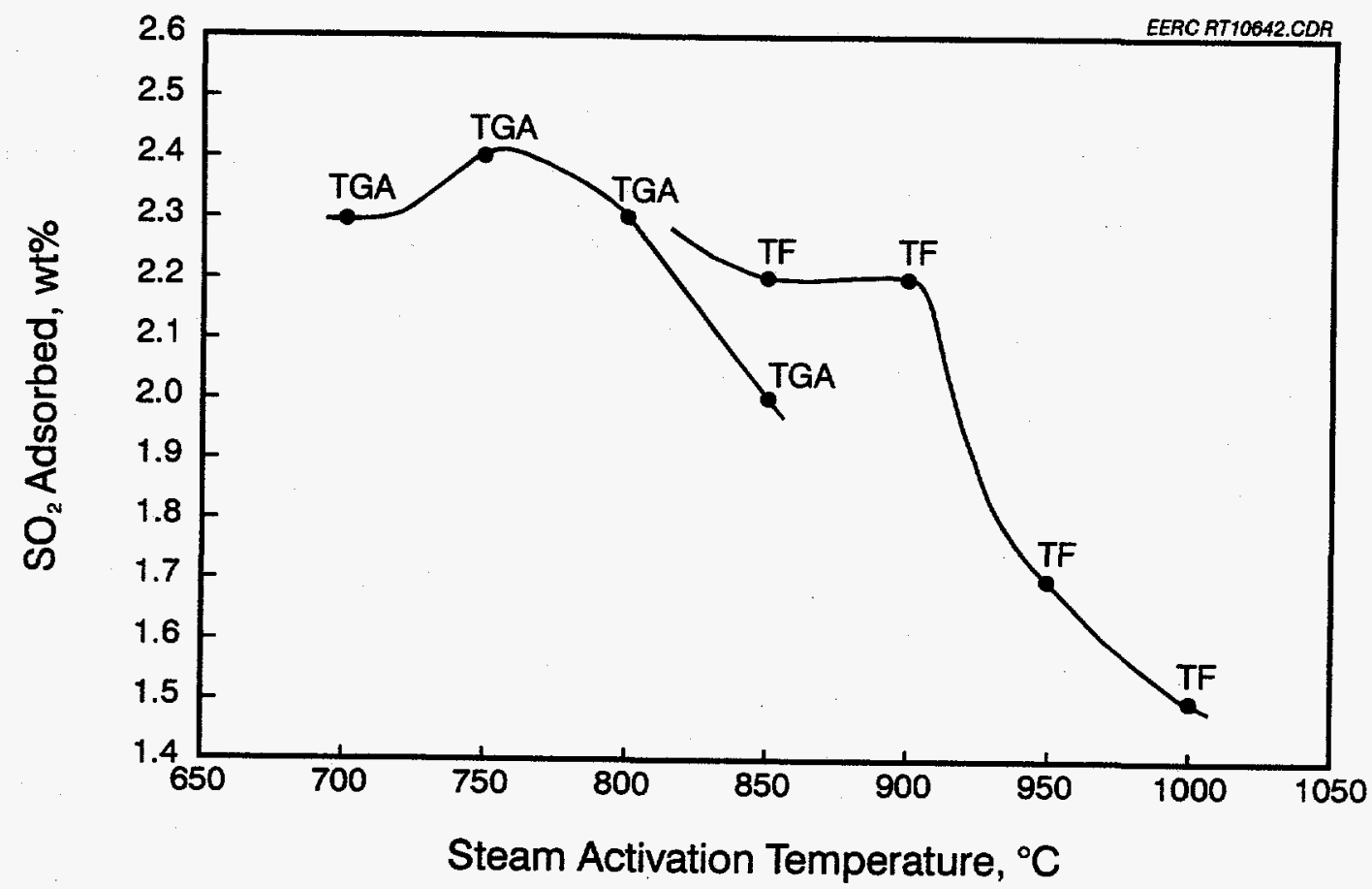

Figure 3. $\mathrm{SO}_{2}$ adsorption from $5000 \mathrm{ppm} \mathrm{SO}_{2}$ in argon at $100^{\circ} \mathrm{C}$. 


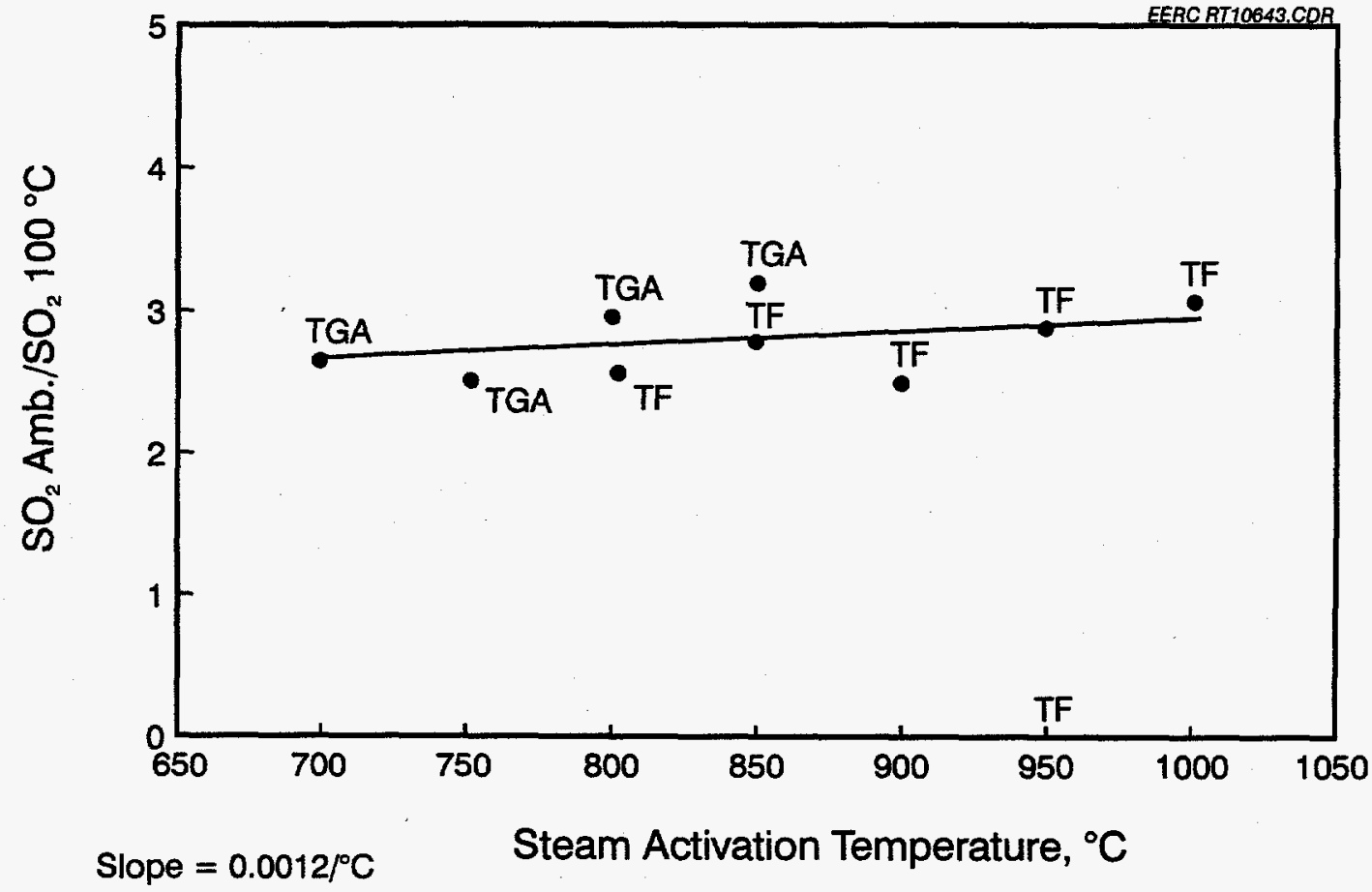

Figure 4. Ratio of $\mathrm{SO}_{2}$ sorption capacity at ambient temperature to sorption capacity at $100^{\circ} \mathrm{C}$ versus steam activation temperature.

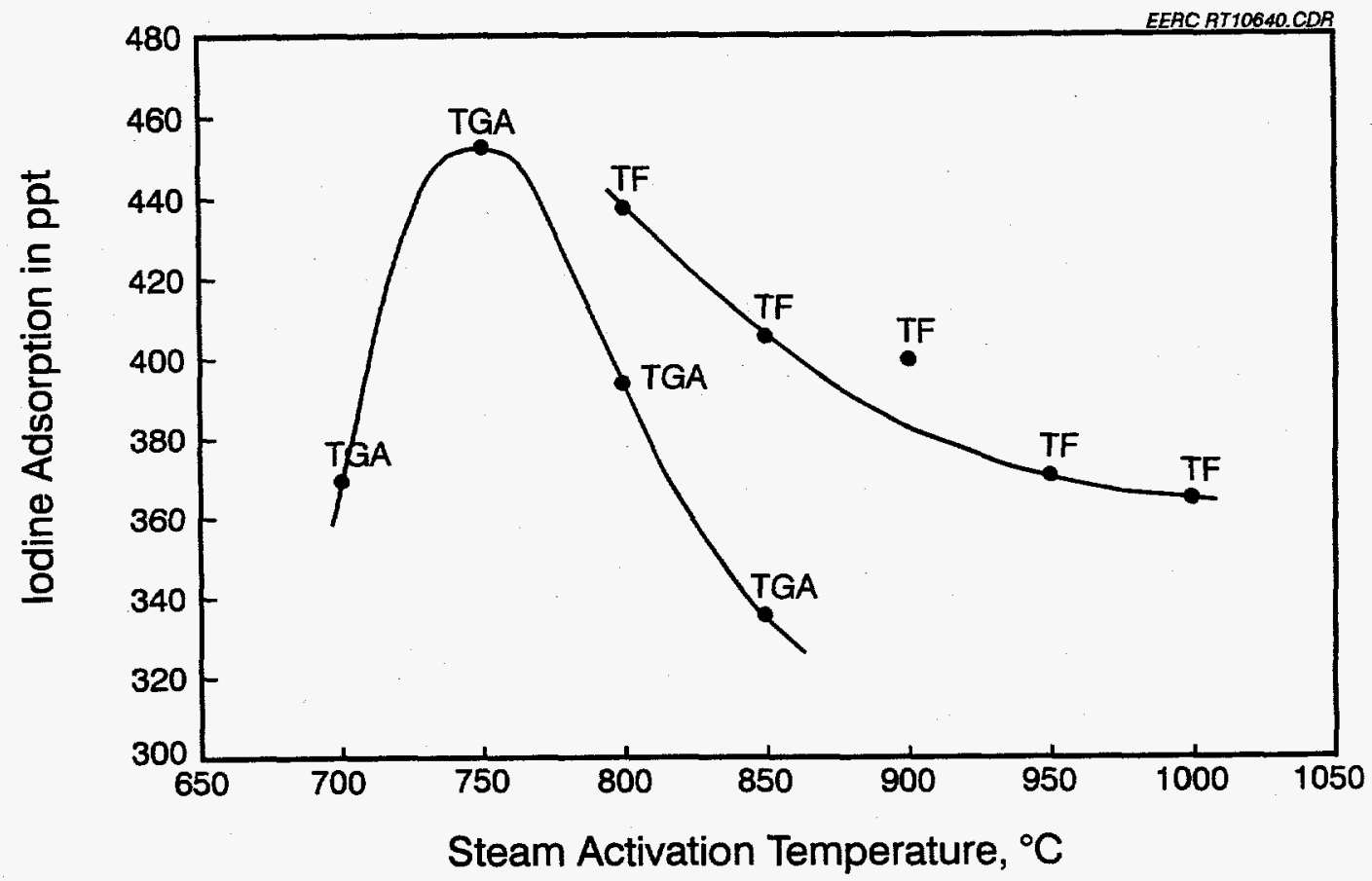

Figure 5. Sorptive capacity for $\mathrm{I}_{2}$ of chars steam-activated at increasing temperatures. 
Figure 2 shows $\mathrm{SO}_{2}$ adsorption at ambient temperature by leonardite char activated at several temperatures. The char produced at $850^{\circ} \mathrm{C}$ shows the greatest $\mathrm{SO}_{2}$ sorption capacity of those produced in the TF. At activation temperatures higher than $850^{\circ} \mathrm{C}$, a decrease in activity with increasing activation temperature is noted. The char activated at $800^{\circ} \mathrm{C}$ in the TGA shows the highest $\mathrm{SO}_{2}$ sorption capacity of those activated.

Figure 3 shows $\mathrm{SO}_{2}$ adsorption at $100^{\circ} \mathrm{C}$. Char activated in the TGA shows maximum sorption capacity at $750^{\circ} \mathrm{C}$ followed by decreasing capacity with increasing temperature. Similarly, the char activated in the TF had a maximum at $850^{\circ} \mathrm{C}$ followed by a slight decrease with temperatures up to $900^{\circ} \mathrm{C}$ and then a rapid decrease in sorption capacity up to $1000^{\circ} \mathrm{C}$.

Since Figures 2 and 3 showed similar trends but apparently differed by a constant, the ratio of the $\mathrm{SO}_{2}$ adsorption values at the two temperatures was plotted against activation temperature. Figure 4 shows the near linearity, with a slope of $0.0012 /{ }^{\circ} \mathrm{C}$. For this set of tests, $\mathrm{SO}_{2}$ adsorption can be predicted with reasonable accuracy using the following equation:

$$
\%_{\text {Amb }} \mathrm{SO}_{2}=2.79 \times \%_{100^{\circ} \mathrm{C}}
$$

Figure 5 shows iodine adsorption as a function of activation temperature. The trend of iodine adsorption for the samples activated in the TF is similar to the $\mathrm{SO}_{2}$ sorption behavior, but those of the samples activated in the TGA exhibit a much steeper slope than those of the TF. However, for $\mathrm{SO}_{2}$, the slope of the TGA curve was markedly less than that of the TF samples. It appears from this limited data set that the iodine number gives a sharper focus with regard to optimum conditions for maximum sorption than does the $\mathrm{SO}_{2}$ sorptive capacity. The maximum values of the iodine number occurred on chars prepared in the TGA at $750^{\circ} \mathrm{C}$ and in the TF at $800^{\circ} \mathrm{C}$. These are the same activation temperatures that produced the chars having the maximum $\mathrm{SO}_{2}$ sorption capacities when $\mathrm{SO}_{2}$ adsorption was measured at $100^{\circ} \mathrm{C}$. Nevertheless, the maximum $\mathrm{SO}_{2}$ capacities measured at ambient temperature occurred on chars activated at $800^{\circ} \mathrm{C}$ (TGA) and $850^{\circ} \mathrm{C}$ (TF), i.e., chars activated at temperatures $50^{\circ} \mathrm{C}$ higher than those giving maximum $\mathrm{SO}_{2}$ capacity when measured at $100^{\circ} \mathrm{C}$ or maximum iodine number. The iodine numbers calculated from single point determinations, which should lie between 600 and $1450 \mathrm{mg} \mathrm{I} / \mathrm{g} \mathrm{C}$ for a commercial active carbon, ranged between 320 and $460 \mathrm{mg} \mathrm{I}_{2} / \mathrm{g}$ char for the leonardite char.

Sorbent prepared from German brown coal by the method of Stadtwerke Dusseldorf was expected to adsorb up to $16 \mathrm{wt} \% \mathrm{SO}_{2}$, but in practice actually adsorbed 10-12 wt\% (1). Marnet, et al. (2) gave similar properties for lignite char and gave $\mathrm{SO}_{2}$-loading values for the sorbent of 10-15 wt \%. GE-Mitsui-BF produces an activated coke that has a sorptive capacity of $6 \%-12 \%$, with a BET surface area of $150-250 \mathrm{~m}^{2} / \mathrm{g}$ (3). By comparison, leonardite char with its high mineral content adsorbed less $\mathrm{SO}_{2}$ than the German or Mitsui chars, but adsorbance by cleaned leonardite was much improved. The BET surface area of the cleaned leonardite was higher than either of the chars mentioned. Additional discussion of these results is found in Section 4.4.

\subsection{Effect of Physical Cleaning}

Silicon, aluminum, iron, and calcium metals make up the major portion of the ash of the Georesources and Gascoyne leonardites (72 and $74 \mathrm{wt} \%$ of the oxygen-free weight in the ash, respectively), but the total weight of these four elements is more than twice as great in the Georesources as in the Gascoyne leonardite (10.6 vs. $4.8 \mathrm{wt} \%)$. At activation temperatures above 
the calcination temperature, the calcium may be converted to calcium oxide, which may be beneficial for trapping $\mathrm{SO}_{2}$ but also deactivates easily at low temperatures in the presence of high concentrations - of $\mathrm{CO}_{2}$. The weight percent of elemental sulfur is greater than $16 \mathrm{wt} \%$ of the oxygen-free Georesources leonardite ash and greater than $12 \mathrm{wt} \%$ of the oxygen-free Gascoyne leonardite ash (this may be beneficial for trapping mercury). Ultimately, however, it may prove beneficial to remove as much of the ash as is feasible before making the activated char for sorbent use.

Washability testing was performed on raw leonardite with Certigrav specific gravity 1.4 and 1.6 and leonardite char which had been prepared in the kiln reactor at $450^{\circ} \mathrm{C}$ under flowing $\mathrm{N}_{2}$ at specific gravity 1.6. The results of proximate analyses of the sink-float fractions are shown in Table 5. The washability results, shown in Table 6, indicate that physical cleaning will reduce the ash in either the raw or carbonized leonardite by more than $55 \%$, with $72 \%-75 \%$ recovery of the feed (dry basis) in the float fraction.

TABLE 5

Proximate Analysis of Georesources Leonardite Sink-Float Fractions

\begin{tabular}{lcccc}
\hline Fraction & $\begin{array}{c}\text { Moisture, } \\
\text { as-received, } \\
\text { wt\% }\end{array}$ & $\begin{array}{c}\text { Volatile Matter, } \\
\text { moisture-free, } \\
\text { wt\% }\end{array}$ & $\begin{array}{c}\text { Fixed Carbon, } \\
\text { moisture-free, } \\
\text { wt\% }\end{array}$ & $\begin{array}{c}\text { Ash, } \\
\text { moisture-free, } \\
\text { wt\% }\end{array}$ \\
\hline Float 1.6 & 22.3 & 38.4 & 51.7 & 9.9 \\
Sink 1.6 & 6.1 & 29.4 & 13.2 & 56.7 \\
Float 1.4 & 42.9 & 51.2 & 41.8 & 7.0 \\
Sink 1.4 & 15.8 & 29.0 & 13.3 & 57.6 \\
\hline
\end{tabular}

TABLE 6

Ash Reduction and Solids Recovery from Washability Testing of Leonardite

\begin{tabular}{lccccccc}
\hline & $\begin{array}{c}\text { Specific } \\
\text { Gravity }\end{array}$ & $\begin{array}{c}\text { Weight, } \\
\text { g }\end{array}$ & $\begin{array}{c}\text { Solids, } \\
\text { wt\% }\end{array}$ & $\begin{array}{c}\text { Dry, } \\
\text { g }\end{array}$ & $\begin{array}{c}\text { Solids Recovery, } \\
\text { wt \% }\end{array}$ & $\begin{array}{c}\text { Ash, } \\
\text { wt \% }\end{array}$ & $\begin{array}{c}\text { Ash Reduction, } \\
\%\end{array}$ \\
\hline Raw & - & 150.0 & 64 & 96.5 & - & 22 & - \\
$\quad$ Float & 1.40 & 112.8 & 60 & 68.0 & 72 & 9 & 56 \\
Sink & 1.40 & 31.7 & 83 & 26.2 & 28 & 54 & - \\
Char (K3) & - & 150.0 & 93 & 140.2 & - & 24 & - \\
Float & 1.60 & 112.8 & 92 & 104.1 & 75 & 11 & 55 \\
Sink & 1.60 & 36.8 & 96 & 35.4 & 25 & 62 & - \\
\hline
\end{tabular}




\subsection{Effect of Chemical Cleaning}

Mineral matter content and its alkaline nature are two highly variable properties that can have important consequences on the production of suitable activated carbons. Lignite-based activated carbons typically have a low micropore volume, some $17 \%$ of the pores being micropores versus $35 \%-50 \%$ macropores (4). The macropores contribute little to surface area and hence have a small impact on the adsorption process. Samaras, Diamadopoulos, and Sakellaropoulos (5) have recently shown that the removal of mineral matter improves the micropore volume of activated carbons since the mineral matter catalyzes the pyrolysis and carbonization reactions, leading to an enlargement of the pores. Several inorganic species, such as $\mathrm{Fe}, \mathrm{K}, \mathrm{Mg}, \mathrm{Ca}$, and $\mathrm{Na}$ are likely gasification catalysts, but the mechanism is not well understood. Removal of mineral matter, for example, from Spanish lignites (6), decreases the reactivity of the chars towards carbon dioxide and oxygen and produces random changes in the surface area as a result of structural changes (7). Davini (8) has recently demonstrated that carbons having a significant mineral matter content, particularly if an appreciable amount of iron is present, and an enhanced content of acidic oxygen groups have reduced capacity for $\mathrm{SO}_{2}$ sorption.

The sorptive capacity of the activated char prepared from chemically cleaned leonardite was determined at ambient temperature and at $100^{\circ} \mathrm{C}$ for a 5000 -ppm $(5 \mathrm{k})$ and a 10,000 -ppm $(10 \mathrm{k}) \mathrm{SO}_{2}$ atmosphere. The results are given in Table 7 . Sorption testing with $\mathrm{SO}_{2}$ was typically performed using a moisture-free $\mathrm{SO}_{2}$ gas stream. Whereas cleaning the coal with $\mathrm{HCl}$ essentially removed the moisture-free $\mathrm{SO}_{2}$ sorption properties from the leonardite, additional treatment with $\mathrm{HF}$ appeared to restore some of the activity. This may be explained by the high volatiles content of the char prepared from the cleaned leonardite as shown in Table 4 resulting from retention of moisture and chlorideblocking active sites, reducing the availability of active sites for adsorption of $\mathrm{SO}_{2}$. However, as seen in Table 7, an increase in adducted weight from the gas stream of more than $50 \%$ was noted when sorption occurred from an $\mathrm{H}_{2} \mathrm{O}$-saturated gas stream containing $5000 \mathrm{ppm} \mathrm{SO}_{2}$ as compared with a dry $\mathrm{SO}_{2}$ stream.

\subsection{Surface Area and Porosity of Selected Samples}

The surface area and porosity of selected samples of activated char prepared from coal were determined using $\mathrm{N}_{2}$ BET and mercury porosimetry, respectively, as described above, and the results are shown in Tables 8 and 9. One experimental activated char prepared in Australia from a North Dakota lignite and KOH was tested along with the EERC chars and the commercial char (9). The Centaur activated char is a commercially available activated char prepared by a proprietary method from bituminous coal. The leonardite, physically and chemically cleaned leonardite, and lignite are North Dakota coals from which activated chars were prepared and characterized as described above.

The surface area is the total area available to adsorb $\mathrm{N}_{2}$, including internal surface of the particles. It was observed during these determinations that substantial moisture was evolved from North Dakota chars under vacuum, requiring extraordinary degassing time in order to remove the moisture and provide accurate measurement of surface area. The long degassing time required indicates large surface area in the form of small pores, implying a large surface area. As can be seen in Table 8, the surface areas of the Australian prepared char and the Centaur char were very high, making each an excellent candidate for sorption application. In addition, each adsorbed a substantial quantity of $\mathrm{SO}_{2}$ but did not substantially retain it in the absence of reduced partial pressure of $\mathrm{SO}_{2}$ in the gas stream, as shown in Table 9, making them candidates for regeneration. Although 


\section{TABLE 7}

$\mathrm{SO}_{2}$ Sorption by Char Prepared from Raw and Chemically Cleaned Leonardite Carbonized under $\mathrm{N}_{2}$ at $480^{\circ} \mathrm{C}$ and Activated at $750^{\circ} \mathrm{C}$.

\begin{tabular}{|c|c|c|c|c|c|}
\hline $\begin{array}{l}\text { Coal } \\
\text { Treatment }\end{array}$ & Atmosphere & Time, $\min$ & $\begin{array}{c}\text { Ambient } \\
(5 \mathrm{k}), \mathrm{wt} \% \text {, } \\
\text { maf }^{1}\end{array}$ & $\begin{array}{c}100^{\circ} \mathrm{C} \\
(5 \mathrm{k}), \\
\mathrm{wt} \%, \text { maf } \\
\end{array}$ & $\begin{array}{c}\text { Ambient } \\
(10 \mathrm{k}), \mathrm{wt} \% \text {, } \\
\text { maf }\end{array}$ \\
\hline None & $\cdots$ & - & - & - & - \\
\hline None & Steam & 60 & 5.9 & 1.8 & 7.3 \\
\hline None & Steam & 40 & 6.1 & 1.8 & 7.5 \\
\hline None & Steam & 20 & 7.3 & 2.1 & 8.4 \\
\hline None & Steam & 10 & 6.4 & - & 9.0 \\
\hline None & $\mathbf{N}_{2}$ & 0 & 7.1 & - & 9.2 \\
\hline HCl Leach & Steam & 60 & 1.3 & 0.2 & - \\
\hline $\begin{array}{l}\mathrm{HCl}, \mathrm{HF} \\
\text { Leach }\end{array}$ & Steam & 60 & 3.8 & 1.9 & - \\
\hline $\begin{array}{l}\mathrm{HCl}, \mathrm{HF} \\
\text { Leach }\end{array}$ & Steam & 10 & - & $2.9^{2}$ & - \\
\hline
\end{tabular}

${ }^{1}$ Moisture- and ash-free.

${ }^{2}$ Adsorption from humidified gas.

TABLE 8

BET $\left(\mathrm{N}_{2}\right)$ Surface Area of Treated Leonardite and Other Experimental and Commercial Char

\begin{tabular}{lc}
\hline Sample & $\begin{array}{c}\text { Surface Area, } \\
\mathrm{m}^{2} / \mathrm{g}\end{array}$ \\
\hline Leonardite-KOH & 2.49 \\
Acid-Cleaned Leonardite & 390 \\
1.6 Float Leonardite & 445 \\
Australian & 920 \\
Centaur & 712 \\
\hline
\end{tabular}


TABLE 9

Pore Structural Characterization of Commercial and North Dakota LRC Carbon

\begin{tabular}{|c|c|c|c|c|}
\hline & $\begin{array}{c}\text { Centaur } \\
\text { Char }\end{array}$ & $\begin{array}{c}\text { Australian-KOH } \\
\text { Char } \\
\end{array}$ & $\begin{array}{c}\text { ND } \\
\text { Leonardite } \\
\text { Char } \\
\end{array}$ & $\begin{array}{c}\text { ND Lignite } \\
\text { Char }\end{array}$ \\
\hline Moisture, as-received, wt\% & 2.9 & 3.0 & 1.1 & 4.7 \\
\hline $\begin{array}{l}\text { Volatiles, moisture-free, } \\
\text { wt } \%\end{array}$ & 1.4 & 3.8 & 8.4 & 13.4 \\
\hline $\begin{array}{l}\text { Fixed Carbon, moisture- } \\
\text { free, wt\% }\end{array}$ & 93.4 & 89.5 & 53.6 & 56.1 \\
\hline Ash, moisture-free, wt \% & 5.2 & 6.7 & 38.0 & 30.4 \\
\hline $\begin{array}{l}\mathrm{SO}_{2} \text { Adsorbed, Ambient, } \\
\text { wt } \%\end{array}$ & 9.3 & 9.4 & 9.0 & 9.7 \\
\hline $\begin{array}{l}\mathrm{SO}_{2} \text { Desorbed, Ambient, } \\
\text { wt } \%\end{array}$ & 5.6 & 7.6 & 4.2 & 2.1 \\
\hline $\mathrm{SO}_{2}$ Retained, wt $\%$ & 3.7 & 1.8 & 4.8 & 7.6 \\
\hline Bulk Volume, $\mathrm{cm}^{3} / \mathrm{g}$ & 1.32 & 1.30 & 1.25 & 1.28 \\
\hline Pore Volume, $\mathrm{cm}^{3} / \mathrm{g}$ & 0.42 & 0.18 & 0.59 & 0.66 \\
\hline Density, $\mathrm{g} / \mathrm{cm}^{3}$ & 0.76 & 0.77 & 0.80 & 0.79 \\
\hline $\begin{array}{l}\text { Porosity, (pore volume/bulk } \\
\text { volume) }\end{array}$ & 0.32 & 0.14 & 0.47 & 0.52 \\
\hline
\end{tabular}

the surface areas of the chars prepared at the EERC were less than those prepared by the Australian process and the Centaur, they had more than twice the surface area of previous samples prepared from North Dakota coals. Adsorption of $\mathrm{SO}_{2}$ by the EERC chars was as good as the Australian and Centaur chars but retention was 2 to 4 times that of the latter two. Calculated on a carbon basis, the $\mathrm{SO}_{2}$ retention of the EERC leonardite char is 1.7 times as much $\mathrm{SO}_{2}$ as the Centaur.

The bulk volume used to calculate porosity is the volume of the entire sample as determined by $\mathrm{Hg}$ displacement at ambient pressure. Some of the bulk volume may be porous, but void of $\mathrm{Hg}$, since liquid $\mathrm{Hg}$ is excluded from all pores of diameter less than $14 \mu \mathrm{m}$ (as defined by the Young-LaPlace theorem). The pore volume is described as that internal space having orifices less than $14 \mu \mathrm{m}$, which is grouped into macropores, mesopores, and micropores. As the $\mathrm{Hg}$ pressure is increased, the successively smaller pores are infiltrated with mercury.

If data from another analytical method supports the contention that small meso- and micropores are present in the sample, a small $\mathrm{Hg}$ porosity number indicates that the size of the pores tends 
toward the smaller pore sizes. In principle, a pressure of 300,000 psig would force $\mathrm{Hg}$ into micropores of $<5 \times 10^{-4} \mu \mathrm{m}(<5 \AA)$ resulting in an accurate estimate of micropore volume although, in practice, this accuracy is of questionable value and is not possible with current equipment at the EERC.

\subsection{SUMMARY}

- Leonardite carbonized at $480^{\circ} \mathrm{C}$ produces char with highest $\mathrm{SO}_{2}$ sorptive capacity and highest iodine number when activated with steam between $750^{\circ}$ and $850^{\circ} \mathrm{C}$.

- Reduction of inert mineral material (ash) in the leonardite (or carbonized leonardite) results in an increase in $\mathrm{SO}_{2}$ uptake on a $\mathrm{mg} \mathrm{SO}_{2} / \mathrm{g}$ char basis.

- Measured differences in activity between chars activated at the same temperature in the TGA versus the TF probably result from differences in heating characteristics of the two reactor configurations; i.e., the sample in the TGA receives no heat via conduction from the reactor wall, resulting in more uniform sample heating than the sample in the TF, which is heated primarily by conduction from direct contact with the wall.

- The difference in $\mathrm{SO}_{2}$ uptake at ambient temperature vs. $100^{\circ} \mathrm{C}$ is probably a result of the relatively large amount of physiosorption occurring on the cooler surface caused by bonding that is too weak to retain the sorbate in the presence of increased thermal energy.

- German reports of char preparation show $\mathrm{SO}_{2}$ uptake of $10 \%-15 \%$ at $70^{\circ}-90^{\circ} \mathrm{C}$. It is difficult to get the details of their measurement method to know exactly how our results compare, although their reported face values are at least a factor of 4 above the values we obtain at $100^{\circ} \mathrm{C}$.

- BET surface area of physically cleaned North Dakota leonardite was approximately $440 \mathrm{~m}^{2} / \mathrm{g}$ and that of acid-cleaned North Dakota lignite was $390 \mathrm{~m}^{2} / \mathrm{g}$, which are nearly twice as great as char prepared from raw coal tested previously. This indicates that presence of mineral material decreases surface area and the resulting adsorption capacity.

- $80 \%$ of adsorbed $\mathrm{SO}_{2}$ is retained by the EERC North Dakota lignite activated char as compared with $40 \%$ of the Centaur char under conditions of reduced $\mathrm{SO}_{2}$ partial pressure, indicating that chemisorption plays a greater role in the EERC lignite char than in the commercial char.

- Although the surface areas of the Centaur char and the Australian char are more than twice as great as those of the EERC low-rank coal chars, the $\mathrm{SO}_{2}$ sorption of the latter under the test conditions is the same. 


\subsection{RECOMMENDATIONS}

- Activated char should be prepared and tested as adsorbant for gaseous mercury species.

- Activated char should be prepared and tests as a medium for water cleanup.

\subsection{PAPERS AND PRESENTATIONS}

Young, B.C.; Olson, E.S.; Knudson, C.L.; Timpe, R.C. "Activated Carbons from North Dakota Lignite and Leonardite," ACS Preprints-209th ACS National Meeting 1995, 40 (2), 280.

\subsection{REFERENCES}

1. Bewerunge, J.; Ritter, G. "The Use of Lignite Coke for Flue Gas Cleanup in Refuse Incineration Plants," Paper presented at GVC Conference on Disposal of Special Refuse by Incineration, Baden-Baden, Dec. 4-6, 1989.

2. Marnet, C.; Kassebohm, B.; Asmuth, P. "Use of Lignite Coke for Reduction of $\mathrm{NO}_{\mathrm{x}}$ after Flue Gas Desulfurization, " In Proceedings on the 4th Biennial Lignite Symposium on the Technology and Utilization of Low-Rank Coals, Dallas, TX, May 18-21, 1987.

3. Tsuji, K.; Shiraishi, I.; Dague, R.F. "The Activated Coke Process for Combined $\mathrm{SO}_{\mathbf{x}} / \mathrm{NO}_{\mathbf{x}} / \mathrm{Air}$ Toxics Reduction," Presented at the 6th International Symposium of Integrated Energy and Environmental Management, Air and Waste Management Association, New Orleans, LA, March 10-12, 1993.

4. Bansal, R.C., Donnet, J.-B., Stoeckli, F. Active Carbon; Marcel Dekker, Inc.: New York, 1988; p. ix

5. Samaras, P.; Diamadopoulos, E.; Sakellaropoulos, G.P. Carbon 1994, 32, 771.

6. Fernandez-Morales, I., Lopez-Garzon, F.J., Lopez-Peinado, A., Moreno-Castilla, C., and Rivera-Utrilla J. Fuel, 1985, 64, 666.

7. Serio, M.A.; Solomon, P.R.; Bassilakis, R. Proc. International Conference on Coal Science, Tokyo, Oct. 1989, pp 341-344.

8. Davini, P. Carbon 1993, 31, 47.

9. Verheyen, T.V.; Guy, P.J. "Preparation of an Extruded High Performance Activated Carbon from North Dakota Lignite," final report to Industrial Commission of North Dakota, Contract No. LMFS-94-13; 1994. 


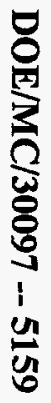

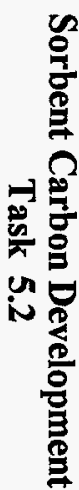

